\title{
Embedding a Threshold Concept in Teaching and Learning of Product Development Management
}

\author{
Paul Coughlan \\ School of Business, Trinity College Dublin \\ Anne Graham \\ School of Education, Waterford Institute of Technology
}

NAIRTL 2009 
Within specific disciplines there exist significant 'threshold concepts', leading to new and previously inaccessible ways of thinking about something.

(Meyer and Land, 2005) 


\section{This paper examines...}

- ...the application of threshold concepts in product development teaching and learning.

- ... an undergraduate degree course in Trinity College Dublin, linking the theory to teaching principles and to learning activities.

- The students are drawn from two separate disciplines with their own unique 'ways of teaching and practicing' (Entwistle, 2005): business and manufacturing engineering, creating an opportunity to combine curriculum content and teaching practice from both disciplines. 


\section{New product development management practice...}

- ...is moving towards a multifunctional and crossdisciplinary focus which means that university graduates need to be able to deal with nonlinearity, emergence and self-organization. 


\section{Here there is a challenge facing teachers}

\begin{tabular}{|c|c|c|}
\hline $\begin{array}{r}\text { How to } \frac{\text { Talk }}{\text { with }} \\
\text { If you Think like }\end{array}$ & Engineer & Manager \\
\hline Engineer & $\begin{array}{l}\text { Starting point: } \\
\text { Once the technical issues } \\
\text { are solved, the rest is } \\
\text { routine }\end{array}$ & $\begin{array}{r}\text { Arrival point: } \\
\text { There is a complex set of } \\
\text { interactions to be } \\
\text { managed in order to get } \\
\text { the product from idea to } \\
\text { market }\end{array}$ \\
\hline Manager & $\begin{array}{l}\text { Arrival point: } \\
\text { There is a complex set of } \\
\text { interactions to be } \\
\text { managed in order to get } \\
\text { the product from idea to } \\
\text { market }\end{array}$ & $\begin{array}{r}\text { Starting point: } \\
\text { Once the commercial } \\
\text { decision is made to } \\
\text { develop, the rest is } \\
\text { routine }\end{array}$ \\
\hline
\end{tabular}




\section{Threshold Concepts are...}

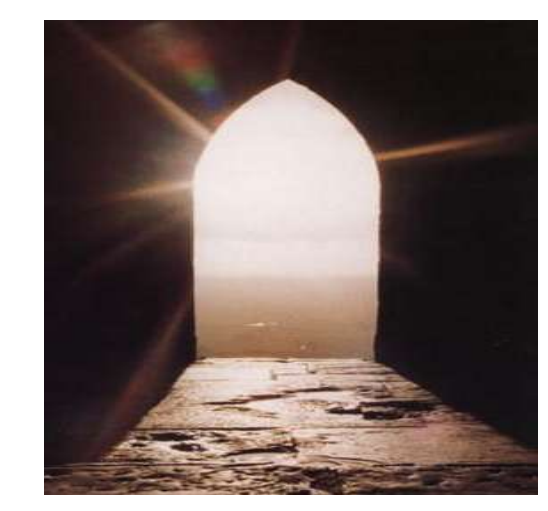

...akin to a portal opening up a new and previously inaccessible way of thinking about something.

...represent a transformed way of understanding, or interpreting, or viewing something without which the learner finds it difficult to progress, within the curriculum as formulated. 


\section{What are the characteristics of a threshold concept?}

- transformative

- irreversible

- integrative

- bounded

- troublesome 


\section{The "Managing New Product Development" course challenges students to analyse such issues}

as...

- Success \& failure in new product development

- The strategic dimension of new product development

- The product development process

- Organisational interfaces in new product development

- Incorporating design into the new product development process

- Target costing and value engineering

- Design for manufacture

- Evaluating and improving the new product development process 


\section{Viewing product development as a complex adaptive system (CAS)...}

- ...provides a framework for managers and engineers to manage and to improve this area.

- Three related but different perspectives on product development used in the MNPD course together lead to the embedding of CAS as a threshold concept:

- Product development as a linear conversion process

- Product development as a recursive system

- Product development as a complex adaptive system 


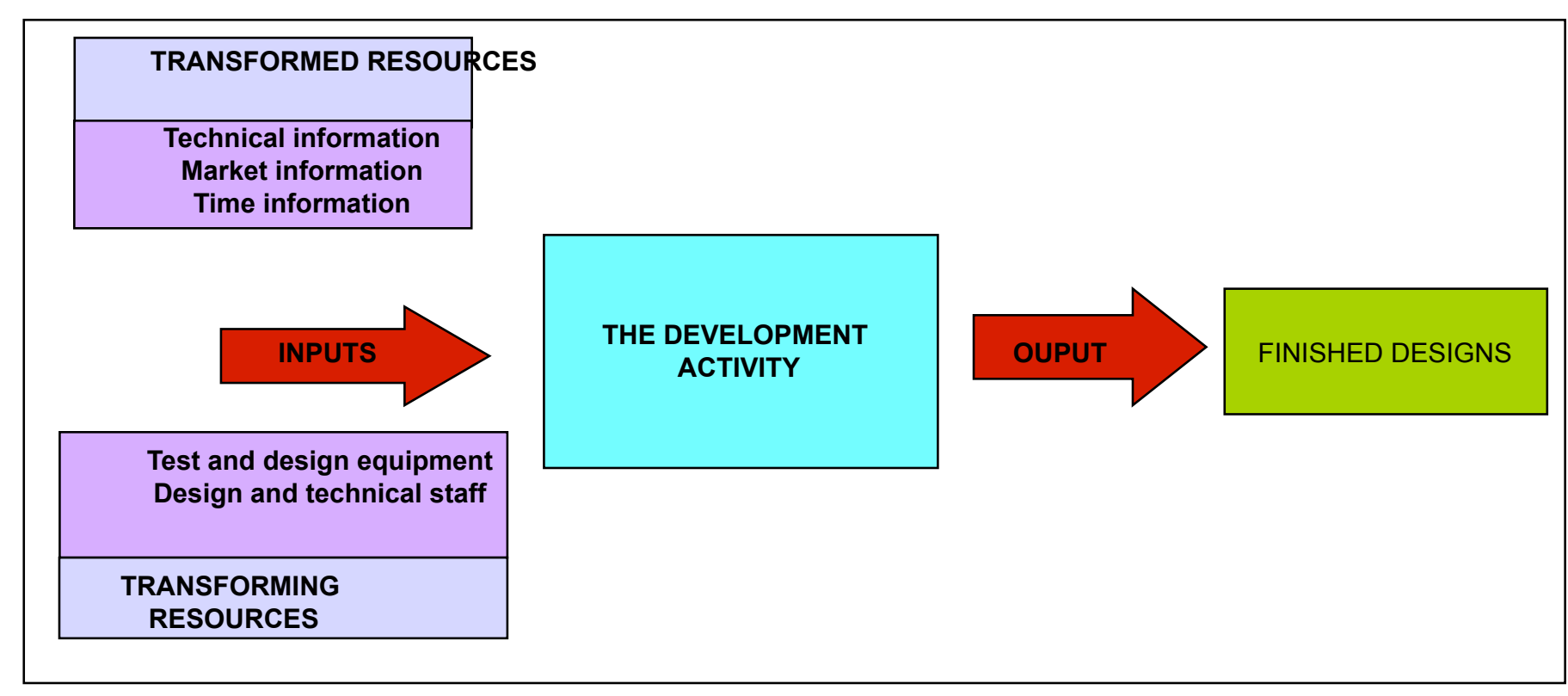

Product

development

as a basic

LINEAR

conversion

process

1

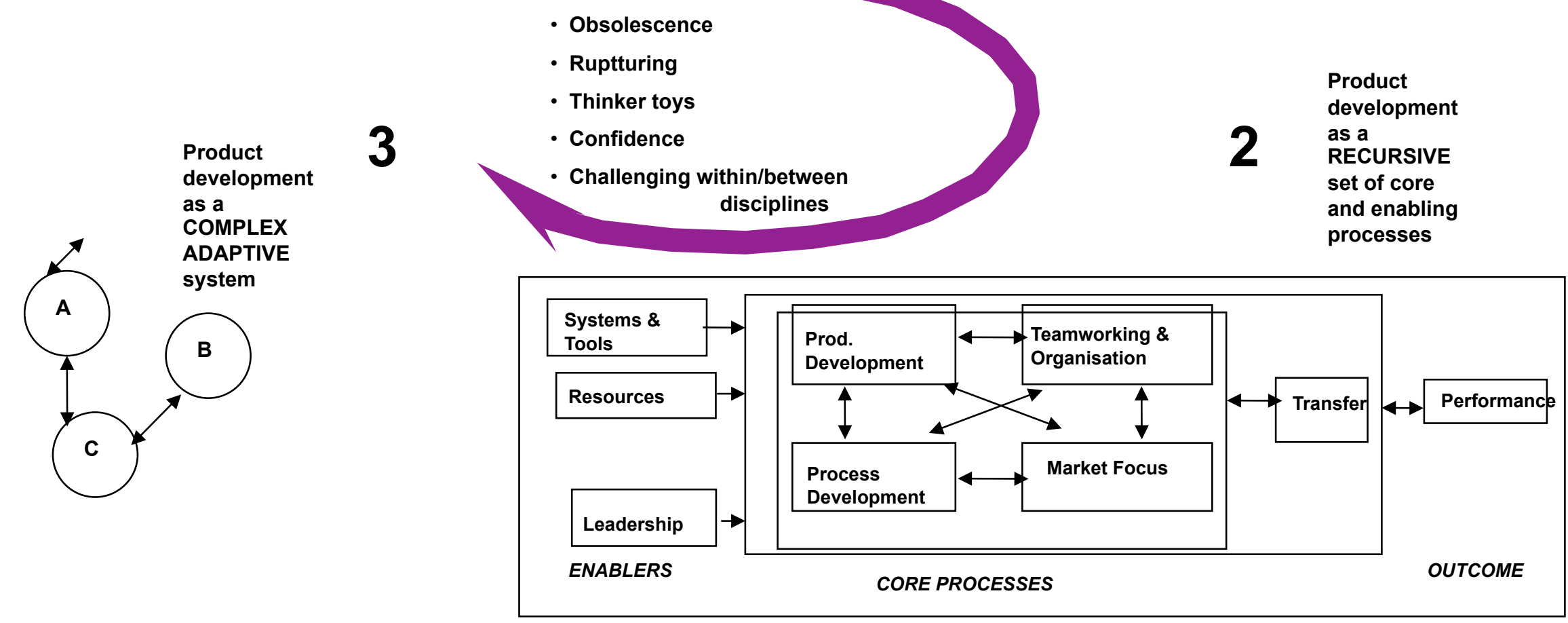




\section{Reflecting on product development as a CAS in terms of a threshold concept}

\begin{tabular}{|l|l|}
\hline Attribute & Evidence \\
\hline Transformative & $\begin{array}{l}\text { The concept of product development as a CAS challenges the } \\
\text { student's perception of themselves and of the subject }\end{array}$ \\
\hline Irreversible & $\begin{array}{l}\text { The student does not return to viewing the area as a function } \\
\text { or a technical task }\end{array}$ \\
\hline Integrative & $\begin{array}{l}\text { The scope of the core and enabling processes brings together } \\
\text { a variety of discipline and functional areas to be managed }\end{array}$ \\
\hline Bounded & $\begin{array}{l}\text { The scope of the core and enabling processes at the levels of } \\
\text { the firm and of the project helps to define the boundaries of a } \\
\text { subject area and clarifies the scope of the communities of } \\
\text { research and practice }\end{array}$ \\
\hline Troublesome & $\begin{array}{l}\text { Seeing product development as a CAS is taken for granted by } \\
\text { many practitioners. The associated knowledge is tacit, alien } \\
\text { to disciplinary-bounded students, and conceptually difficult }\end{array}$ \\
\hline
\end{tabular}




\section{Helping Learners To Identify Threshold Concepts is difficult}

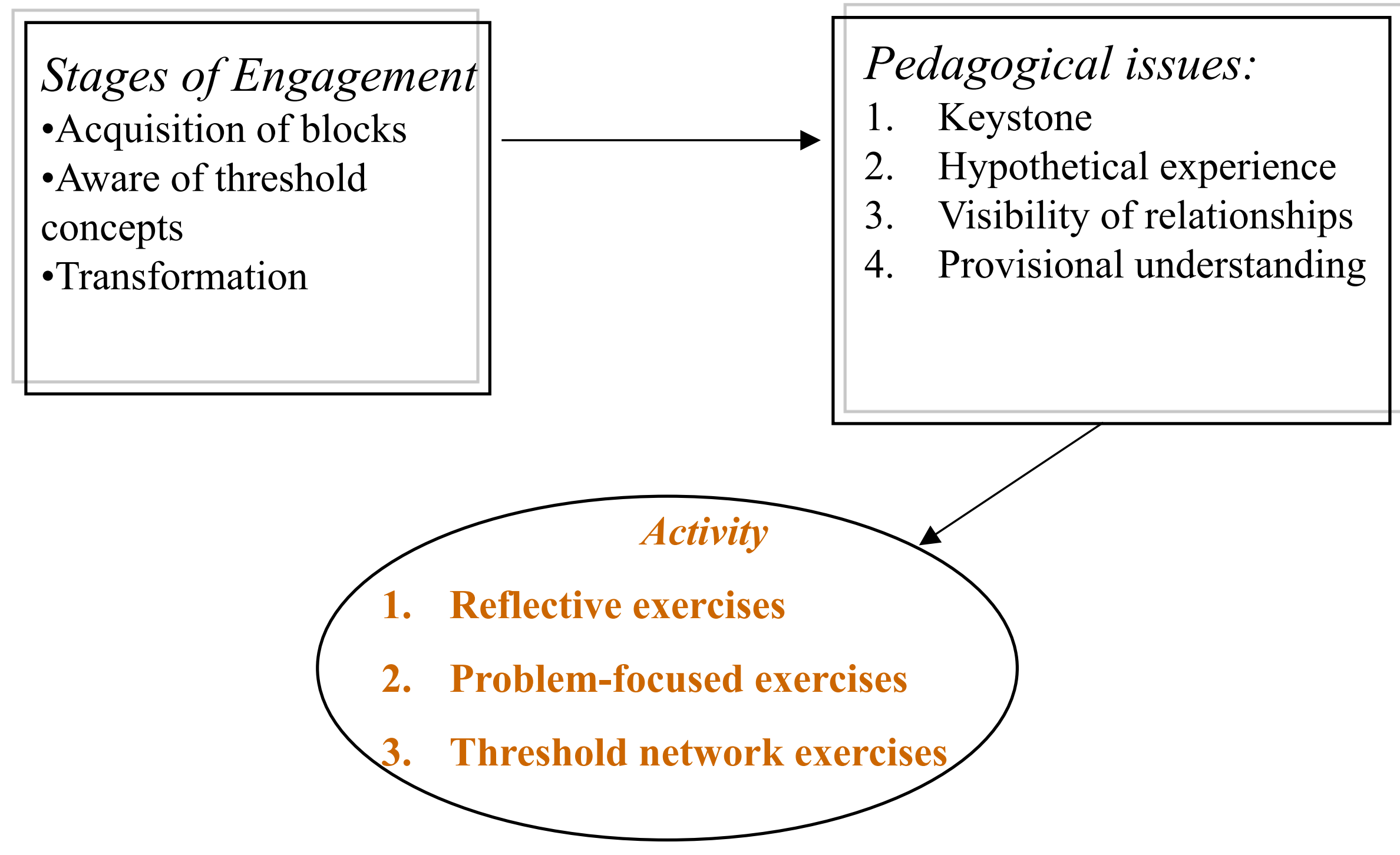




\section{Product Development as a CAS - Pedagogical Issues and Principles}

\begin{tabular}{|l|l|l|}
\hline Pedagogical Issues & $\begin{array}{l}\text { Pedagogical Principles and } \\
\text { Activities }\end{array}$ & $\begin{array}{l}\text { Application to the MNPD } \\
\text { Course }\end{array}$ \\
\hline $\begin{array}{l}\text { The threshold concept acts } \\
\text { as a keystone }\end{array}$ & $\begin{array}{l}\text { Highlight variation to ensure } \\
\text { sufficient foundation of basic } \\
\text { concepts }\end{array}$ & $\begin{array}{l}\text { Product development as a } \\
\text { CAS brings form and } \\
\text { robustness }\end{array}$ \\
\hline $\begin{array}{l}\text { The threshold concept is } \\
\text { distant initially from } \\
\text { direct experience and can } \\
\text { only be experienced } \\
\text { hypothetically }\end{array}$ & $\begin{array}{l}\text { Integrate understanding through } \\
\text { re-working previously acquired } \\
\text { concepts in the light of the } \\
\text { threshold concept }\end{array}$ & $\begin{array}{l}\text { The hypothetical experience } \\
\text { of product development as a } \\
\text { CAS is experienced through } \\
\text { comparative case analysis }\end{array}$ \\
\hline $\begin{array}{l}\text { The threshold concept } \\
\text { becomes visible through } \\
\text { engaging in a new way of } \\
\text { practising and of thinking }\end{array}$ & $\begin{array}{l}\text { Expose how scholars use } \\
\text { procedural thresholds by } \\
\text { highlighting variation in the use } \\
\text { of key procedures }\end{array}$ & $\begin{array}{l}\text { Product development as a } \\
\text { through the field project }\end{array}$ \\
\hline $\begin{array}{l}\text { The acquisition of a } \\
\text { threshold concept } \\
\text { transforms understanding } \\
\text { of previously acquired } \\
\text { subject knowledge }\end{array}$ & $\begin{array}{l}\text { Help students to regard their } \\
\text { understanding as provisional } \\
\text { and to tolerate uncertainty }\end{array}$ & $\begin{array}{l}\text { The sequential presentation } \\
\text { of each perspectives } \\
\text { develops provisional subject } \\
\text { knowledge }\end{array}$ \\
\hline
\end{tabular}




\section{Feedback has come from a number of sources...}

- CAPSL surveys

- $99 \%$ found the course good or excellent

- The project

- 'Overall, this [course] has been one of the most enjoyable and worthwhile in a practical sense, not just this year, but in my entire college career'.

- 'The project enabled us to gain tremendous insight into the practical application of the theory we had studied throughout the course. Many of the issues that we identified within (the company) were similar to those we had seen in the case studies in class and the experience complemented our learning greatly. Likewise, it was helpful to have covered cases beforehand which aided us in understanding the kinds of issues facing [such companies]'.

- The project companies

- 'The management team are very impressed with the assessment of the company by [the students]'. 


\section{So, in summary}

- From a pedagogical perspective, a threshold concept has potential to encourage students towards deep rather than surface learning

- It is best introduced when students have

- acquired sufficient subject knowledge to develop and to practise an integrated understanding.

- Embedding the concept requires that it becomes visible through engaging in a facilitated way of practising and of thinking where students accept that, at each stage in their learning, their understanding is provisional. 